УДК 347.948.2

DOI https://doi.org/10.32837/pyuv.v2i4(29).436

\author{
Л. В. Мамчур \\ orcid.org/0000-0003-1148-4306 \\ кандидат юридичних наук, доиент, \\ доцент кафедри иивільного та крилінального права і процесу \\ Чорнолорського національного університету ілені Петра Могили \\ М.О. Мельніков \\ orcid.org/ 0000-0002-4034-2713 \\ магістрант II року навчання \\ юридичного факультету \\ Чорноморського національного університету імені Петра Могили
}

\title{
ВИСНОВОК ЯК ПРОЦЕСУАЛЬНА ФОРМА ВИКОРИСТАННЯ ФАХОВИХ ЗНАНЬ ЕКСПЕРТА 3 ПИТАНЬ ПРАВА В ЦИВІЛЬНОМУ ПРОЦЕСІ УКРАЇНИ
}

Постановка проблеми. Тлумачення права в офіційному і неофіційному вигляді не сприяє однаковому застосуванню права під час ухвалення рішень судами. Залучення фахівця у сфері права до судового провадження було започатковано змінами до Цивільного процесуального законодавства України.

Належне застосування правових норм є запорукою правосудних рішень. Законодавство України передбачає можливість використання судами декількох дієвих способів установлення змісту правових норм, серед яких важливе місце посідає висновок експерта з питань права.

Аналіз останніх досліджень і публікацій. Процесуальна регламентація правового статусу експерта 3 питань права за останні кілька років аналізувалася у працях I. Бутирської, О. Кармази, Д. Кушерця, Ю. Рябченко, М. Шепітько, А. Штефана, І. Озерського, Н. Зозулі й ін.

Формулювання мети статті. Мета наукової статті - дослідити необхідність визнання висновку експерта з питань права доказом, визначити ступінь його обов' язковості для суду.

Виклад основного матеріалу. Влада продовжує судову реформу, розпочату у 2014 р. Наприкінці 2017 р. відбувся перегляд законодавчих приписів процесуальних кодексів України - внесено однотипні зміни до Цивільного, Господарського, Кримінального кодексів та Кодексу адміністративного судочинства. Однією з істотних новел у процесуальних кодексах є запровадження нового учасника процесу - експерта з питань права, чий правовий статус прописано вперше.

Після виборів Президента у 2019 р. напрями реформування судової системи було переглянуто. Серед пропонованих змін до Цивільного процесуального кодексу України (далі - ЦПК України) $€$ пропозиція визнати висновок експерта з питань права доказом [1]. На нашу думку, вирішення цього питання є ключовим для повноцінної детермінації процесуального статусу експерта з питань права.
Залучення експерта з питань права використовується щоразу, коли в суду виникає потреба тлумачення правових норм із боку кваліфікованого спеціаліста. Дослідники визнають, що не завжди суддя може знатися на всіх нюансах чинного законодавства [2]. Проте допустимі форми отримання правової консультації у правовій науці дискутуються.

Так, відповідно до ч. 2 ст. 8 Закону України «Про міжнародне приватне право», з метою встановлення змісту норм права іноземної держави суд чи інший орган може звернутися в установленому законом порядку до Міністерства юстиції України чи інших компетентних органів та установ в Україні чи за кордоном, або залучити експертів. Водночас, як зазначено в літературі [3], фрактично неможливість використання висновку щодо тлумачення норм іноземного права експерта з питань права як доказу цілком анулює його значення в судовому процесі, оскільки потребує або додаткової перевірки, або ж взагалі звернення до інших компетентних установ чи органів.

Основне ж призначення експерта $з$ питань права в судовому процесі обмежується наданням правової допомоги-консультації, втіленої у форму письмового висновку, у межах і спосіб, визначені ЦПК України, а саме в питаннях, вирішення яких потребує спеціальних знань у галузі міжнародного права та доктринального тлумачення норм права, а також практики його застосування.

Законом передбачено вимоги до змісту висновку експерта з питань права. Це означає, що даний висновок є документом встановленої форми, який має офіційний характер. Проте вважаємо, що цього недостатньо.

Трапляються випадки, коли до матеріалів справи долучаються висновки експерта з питань права, які жодним чином не стосуються спірних правовідносин. Непоодинокі також ситуації, коли сторони долучали до матеріалів справи висновок експерта з питань права, який цілком відображав мотивувальну частину судового рішення [4]. 
Наприклад, у рішенні Сєвєродонецького суду Луганської області від 5 квітня 2018 р. суд зазначив таке: «Суд не сприймає посилання позивача на висновок науково-правової експертизи, складений науковим співробітником $<. . .>$, оскільки вони не є нормативно-правовими актами, за своєю природою мають інформаційно-рекомендаційний та необов'язковий характер, висновок складався за запитом представника позивача» [5]. В іншій справі № 242/293/17, у рішенні Апеляційного суду Донецької області від 11 січня 2018 р. суд зазначив, що наданий висновок є письмовою думкою окремих фахівців у галузі права стосовно спірних правовідносин, висловленою за приватним замовленням відповідача $<. . .>$ i не $€$ належним та допустимим доказом у даній справі та судом до уваги не береться» [6].

Як бачимо, переважно для ухвалення рішення про відмову в долученні висновку експерта з питань права суд керувався ч. 1 ст. 115 ЦПК України, де висновок експерта в галузі права не є доказом, а має допоміжний характер. Обгрунтувалося це тим, що висновок експерта включено до гл. 5 ЦПК України, яка має назву «Докази та доказування». Відповідно до змісту ст. 115 Кодексу, висновок експерта з питань права не є доказом, а має лише допоміжний (консультативний) характер. Тому суд, оцінюючи висновок експерта з питань права, не зобов'язаний був зважати на нього.

Складається враження, що взагалі відпадає потреба в залученні експерта з питань права: суд, по-перше, може не брати до уваги наданий висновок, по-друге, якщо суд посилається в рішенні на висновок експерта в галузі права, він має зробити самостійні висновки щодо відповідних питань [7].

Для подолання суперечності, на нашу думку, досить буде визнати висновок експерта з питань права доказом; такий підхід не порушуватиме принципів незалежності суду, адже остаточне рішення залишиться за суддею. Навпаки, такий підхід дасть змогу судді краще розібратися у тлумаченні і застосуванні правових норм.

Щодо тлумачення норм іноземного права, то надання експертом висновку щодо змісту таких норм, згідно з їх офіційним або загальноприйнятим тлумаченням, практикою застосування і доктриною, що є усталеними у відповідній іноземній державі, $€$ позитивною новелою. Сьогодні в судовій практиці все частіше доводиться звертатися до норм іноземного права, але для того, щоби тлумачити і застосовувати такі норми, необхідні спеціальні знання [7]. Позитивним також є те, що як експерта в таких випадках можна буде залучити й іноземного фахівця, який володіє більш точними і повними знаннями про право, яке підлягає застосуванню.

Практика демонструє, що суди часто не приділяють належної уваги висновкам експерта з питань права через страх виглядати некомпетентними, зазначають, що самостійно здатні вирішити справу без сторонніх фахівців, у галузі права і поготів. Ігнорування суддями можливостей використання інституту експерта з питань права в судовому процесі призводить до формалізації процесу не на користь ухвалення справедливого рішення, про що свідчать підстави для відмови в долученні висновків таких експертів чи їх залучення. На додачу, висновки експерта 3 питань права часто плутають із тлумаченням законодавства та права загалом. Так, у рішенні Сєвєродонецького суду Луганської області від 10 квітня 2018 р. суддя зазначав правничу допомогу, а застосовував норми, які регулюють статус експерта з питань права, ототожнюючи ці процесуальні інститути [5].

Варто зазначити, що у ЦПК законодавець не передбачив норми, відповідно до якої експерт із питань права попереджається про відповідальність за завідомо неправдивий висновок або за відмову без поважних причин від виконання своїх обов'язків. На практиці це може спричинити сумніви щодо достовірності такого висновку [7, с. 123].

Окрім того, багато суперечностей виникає під час встановлення вимог до висновку експерта з питань права. Специфіка даного документа полягає в тому, що в ньому міститься підсумковий висновок аналітичної діяльності експерта, який одержується шляхом логічних умовиводів на підставі наявних спеціальних знань, у нашому випадку - знань у галузі права. Отже, дослідження експерта в галузі права й отримані ним висновки являють собою відповідно процес та результат пізнавальної діяльності, що має суб'єктивно-об'єктивний характер. Чинні нормативно-правові акти визначають лише суб'єктів, цілі, форми та межі такої експертної діяльності.

М. Чернова пише, що «експерт у своєму висновку фактично синтезує нові знання на основі власних спеціальних знань та досвіду, повідомляє суд про факти, встановлені ним на основі використання даних тієї чи іншої галузі науки, техніки, мистецтва. Водночас місія експерта полягає в тому, щоби просвітити суд, і ця місія виключає інтереси сторін» [8, с. 23]. Дослідження, що проводиться експертом із питань права, має задовольняти двом вимогам: об'єктивності й обг'рунтованості. Ці вимоги випливають 3 обов’язку експерта дати обгрунтований і об'єктивний письмовий висновок щодо поставлених йому питань. Наявно чимало інформації стосовно висновку експерта 3 питань права, проте немає чітких критеріїв стосовно обсягу даного документа, переліку суджень, які варто підтвердити чи спростувати, загальної послідовності викладу матеріалу, структури, інших обов'язкових реквізитів.

Слушно зазначає I. Озерський, що «нині юридичною (судовою) практикою не вироблено єдиного зразка бланка такого процесуального документа, як висновок експерта в галузі права, а тому використовуються дещо модифіковані самими експертами в галузі права стандартизовані бланки судових 
експертиз, що грубо порушують цілісність, структурність, методичність, текстуальну логічність, нормативність та відповідність висновку правовим приписам, визначеним у процесуальному законодавстві» .

I. Озерський пропонує модель, згідно з якою у згаданому висновку має бути передбачено ознайомлення експерта із правами, закріпленими в ч. 3 ст. 73 ЦПК України, ч. 3 ст. 70 Господарського процесуального кодексу (далі - ГПК) України та ч. 3 ст. 69 Кодексу адміністративного судочинства (далі - КАС) України, а також з обов' язками, регламентованими в ч. 2 ст. 73 ЦПК України, ч. 2 ст. 70 ГПК України та ч. 2 ст. 69 КАС України. Експерт у бланку висновку має повідомляти, що його попереджено про відповідальність, передбачену для експерта в галузі права ч. 7 ст. 102 ЦПК України, ч. 7 ст. 98 ГПК України, ч. 7 ст. 101 КАС України за відмову без поважних причин від виконання покладених на нього обов'язків, а також із положеннями ч. 2 ст. 185-3 Кодексу України про адміністративні правопорушення за злісне ухилення від явки до суду.

Такий висновок має цілком узгоджуватися із застереженнями, передбаченими в ч. 2 ст. 102 ЦПК України, ч. 2 ст. 98 ГПК України, та ч. 2 ст. 101 КАС України, де зазначено, що «предметом висновку експерта не можуть бути питання права», а також ч. 2 ст. 101 КАС України, з положеннями ч. 2 ст. 114 ЦПК України, ч. 2. ст. 108 ГПК України, ст. 114 КАС України. Експерт у галузі права повинен зазначити, якими саме методиками чи/або технічними засобами, методами, доктринами, концепціями, юридичною практикою він оперував під час виконання експертного завдання (формування висновку) [9]. Запропонована концептуальна модель є досить слушною та може стати в подальшому цікавою темою для досліджень.

Висновки. Залучення експерта з питань права в судовий процес дозволяє вирішити справу з подоланням прогалин і колізій у правовому регулюванні спірних відносин, відповідно до букви і духу закону.

Перспективною нам видається процесуальна модель, за якою врахування суддею спеціальних знань фахівця буде здійснюватися в порядку їх оцінки нарівні з іншою інформацією про події і факти, що зібрана у справі; тобто висновок експерта з питань права варто розглядати як доказ у процесі, а не як допоміжну (консультативну) інформацію. Такий підхід означатиме, що за недостовірний висновок до експерта з питань права можна буде застосовувати заходи відповідальності, а цінність висновку зросте.

Висновок експерта з питань права, що є єдиною допустимою процесуальною формою для проголошення експертної думки, потребує максимальної формалізації через закріплення на рівні процесуальних кодексів вимог до його реквізитів, структури і змісту в частині належності, достовірності, допустимості відповідної інформації. Завдяки цьому викладена у висновку компетентна думка експерта з питань права не буде ігноруватися суддею під час винесення рішення, з іншого ж боку, використання висновку для відтворення в мотивувальній частині судового рішення теж стане неможливим.

\section{Jimepamypa}

1. Іванішин В. Висновок експерта з питань права як доказ. Судово-юридична газета. Верховний Суд України. 2018. URL: https://sud.ua/uk/issue/352.

2. Цивільний процесуальний кодекс України. Biдомості Верховної Ради України. 2004. № № 40-42. Ст. 492. URL: https://zakon.rada.gov.ua/laws/show/1618-15.

3. Щербак С. Правове становище експерта з питань права в цивільному процесі України. Правові горизонти. 2018. Вип. 13 (26). С. 29-32. URL: https:// essuir.sumdu.edu.ua/bitstream/123456789/72657/1/ Shcherbak_pravove_stanovyshche_eksperta.pdf (дата звернення: 12.02.2020).

4. Рішення Дніпровського районного суду м. Києва від 25 січня 2018 р. № 755/15364/17. Єдиний державний реєстр судових рішень. URL: http://reyestr. court.gov.ua/Review/71937133 (дата звернення: 06.09.2019)

5. Рішення Сєвєродонецького суду Луганської області від 18 травня 2018 р. № 428/13694/17. ЄӘиний державний реєстр судових рішень. URL: http://reyestr.court.gov.ua/Review/75057891 (дата звернення: 05.06.2019).

6. Постанова Апеляційного суду Донецької області від 11 січня 2018 р. № 242/293/17. Єәиний державний реєстр судових рішень. URL: http://reyestr. court.gov.ua/Review/71554180 (дата звернення: 05.06.2019).

7. Круковес В. Правовий статус експерта з питань права в цивільному судочинстві України. Актуальні проблеми правознавства. 2019. Вип. 2. С. 122-126. URL: http://nbuv.gov.ua/UJRN/aprpr_2019_2_23.

8. Чернова М. Заключение эксперта как доказательство в гражданском и арбитражном процессе : дис. ... канд. юрид. наук: 12.00 .15 . Москва, 2015. 312 с.

9. Озерський I. Зразок бланку висновку експерта у галузі права. Міжнародна науково-практична конференція, 30 транвя 2019. Секція № 5. Запоріжжя, 2019. URL: http://legalactivity.com.ua/index. php?option=com_content (дата звернення: 12.02.2020).

\section{Анотація}

Мамчур Л. В., Мельніков М. О. Висновок як процесуальна форма використання фахових знань експерта 3 питань права в цивільному процесі України. - Стаття.

У статті досліджено висновок експерта з питань права та його доказову силу в судовому процесі. Автори зазначають загальну позитивність змін у процесуальному законодавстві, націлених на появу у процесі експерта 3 питань права як спеціального учасника судового розгляду, але вказують на потребу визначити єдині підстави для залучення експерта з питань права у процес, які б мінімізували роль розсуду судді під час розгляду конкретної справи.

Детальному аналізу піддано наявні недоліки та суперечності правової регламентації використання фахової думки експерта в частині невизначеності ступеня обов'язковості висновка експерта з питань права як процесуального документа.

Для подолання виявлених недоліків автори пропонують надати висновкові експерта 3 питань права 
статусу процесуального доказу, що в такому випадку повинен залучатися до справи і досліджуватися нарівні з іншими доказами під час розгляду справи по суті. Автори вважають, що такий підхід дозволить повною мірою врахувати такі існуючі принципи цивільного судочинства, як незалежність суду і диспозитивність судового розгляду, й уникнути ототожнення висновку експерта 3 питань права 3 актами офіційного чи неофіційного тлумачення законодавства

Водночас більш чітким виглядатиме процесуальний статус експерта з питань права, оскільки можна, проводячи деякі аналогії зі статусом свідка у процесі, спеціально передбачити відповідну процедуру попередження, у момент залучення до участі у справі, що розглядається, експерта з питань права про його відповідальність за надання завідомо неправдивого висновку або відмову від його надання без поважних причин.

На думку авторів, вимоги до висновку експерта 3 питань права мають бути максимально формалізовані, підтримана ідея щодо розроблення єдиної типової форми такого висновку як базової.

Ключові слова: експерт із питань права, висновок експерта $з$ питань права, права та обов'язки експерта з питань права, учасники судового процесу.

\section{Summary}

Mamchur L. V., Melnikov M. O. Conclusion as a procedural form of the use of professional knowledge of an expert on legal issues in a civil process in Ukraine. - Article.

The article examines the conclusion of an expert on legal issues and his probative value in litigation. The authors note the overall positive nature of changes in procedural law aimed at the emergence of an expert on legal issues as a special participant in the trial. However, there is a need to identify common grounds for involving an expert on legal issues in a process that would minimize the role of a judge's opinion in a particular case. It is analyzed in detail the existing shortcomings and contradictions of the legal regulation of the use of the expert opinion in the part of uncertainty if such conclusion of the expert on the law is obligatory as a procedural document or it is not.

Recommendations are given to provide the expert's opinion the status of procedural evidence, which in this case should be involved in the case and investigated, along with other evidence, in the merits of the case. The authors believe that this approach will fully take into account existing principles of civil justice, such as the independence of the court and the dispositive nature of the trial. Also it will help to avoid identifying an expert on legal issues with official or unofficial interpretation of the law. At the same time, the procedural status of expert on legal issues will be clearer if it is specifically provided for the procedure of warning of his liability for giving a deliberately false conclusion or refusing to give it without good reason at the time of involvement in a case by analogy with the status of a witness. According to the authors, the requirements for the conclusion of expert on legal issues should be formalized as much as possible. The authors support the idea of developing a single typical form of such a conclusion as the basic.

Key words: expert on legal issues, conclusion of expert on legal issues, expert's rights and obligations, parties in court. 